\title{
First workshop of the Asian Network for Environment and Energy
}

\author{
Hội thảo lần thứ nhất của Mạng lưới châu Á về Môi trường và Năng lương
}

Event report

Le, Hung-Anh ${ }^{1}$; Kim, Jo-Chun ${ }^{2}$; Perng, Yuan-Shing ${ }^{3} ;$ Kim, In-Won ${ }^{4}$

${ }^{1}$ Institute for Environmental Science, Engineering and Management, Ho Chi Minh City University of Industry, Vietnam; ${ }^{2}$ Department of Environmental Engineering, Konkuk University, Republic of Korea; ${ }^{3}$ Department of Environmental Engineering, Da Yeh University, 168 University Road, Dacun, Changhua, 51591, Taiwan; ${ }^{4}$ Department of Chemical Engineering, Konkuk University, Republic of Korea

\begin{abstract}
Asia is one of the most densely populated areas in the world. Many Asian countries experienced strong economic growth and rapid urbanization in the last decade. However, Asia is also faced with the challenge of environmental protection, energy security and $\mathrm{CO}_{2}$ emissions. The purpose of establishment of the Asian Network for Environment and Energy (ANEE) is to connect the research and training institutions, facilitate the exchange of experience and know-how, and initiating joint projects on environmental protection and renewable energy. The network organizes annual scientific conferences, develops projects addressing environmental problems of the region, and builds personnel training programs for renewable energy and environment. The first ANEE workshop held in Ho Chi Minh City is the launching event the network addressing air pollution, water management, solid waste and energy.
\end{abstract}

Châu Á là một trong nhũng khu vực đông dân nhất trên thế giới. Nhiều quốc gia tại châu Á đã có sự phát triển kinh tế mạnh mẽ và đô thị hóa rất nhanh trong thập kỷ vùa qua. Tuy nhiên, khu vưc châu Á cũng đối mặt với các thách thức về bảo vệ môi truờng, phát thải $\mathrm{CO}_{2}$ và an ninh năng luợng. Mục đích thành lập Mạng luới châu Á về Môi truờng và Năng luợng (ANEE) nhằm kết nối các tổ chức nghiên cúu và đào tạo, tạo điều kiện cho trao đổi kinh nghiệm và know-how, xây dụng các dư án tổng thể về bảo vệ môi truờng và năng luợng tái tạo. Mạng luới tổ chức các Hội thảo khoa học hàng năm, phát triển các dụ án giải quyết các vấn đề môi truờng thời sụ của khu vục, xây dụng các chuơng trình đào tạo nhân lục ngành môi truòng và năng luợng tái tạo. Hội thảo lần thứ nhất của ANEE đurợc tổ chức tại Tp.Hồ Chí Minh là sụ kiện khởi động Mạng luới với các chuyên đề về Ô nhiễm không khí, Quản lý nguồn nước, chất thải rắn và năng lượng.

Keywords: Asia Network, ANEE, environment, renewable energy

\section{Workshop organization, objective and topics}

The international workshop held on August 24th, 2012 at Ho Chi Minh City University of Industry is the first scientific event of the Asian Network for Environment and Energy (ANEE). Originally, ANEE has three subcommittees: "Air pollution control" - coordinated by the Institute for Indoor Air Quality and Ubiquitous SafetyKonkuk University, "Water treatment and water management" - coordinated by the Department of Environmental Engineering at Da Yeh University, and "Solid waste and energy" - coordinated by the Institute for Environmental Science, Engineering and Management at Ho Chi Minh City University of Industry. The workshop was also di- vided into three sessions according to the above three subcommittees.

The workshop's participants were scientists, teachers, students, and experts from South Korea, Taiwan, Laos and Vietnam. Particularly in the host country, the representatives of 12 universities, five research institutes, and six consulting companies attended the workshop, which included 10 scientific reports (oral presentation), three posters and one seminar. The scientists reported on their research results, ongoing research projects and research focus concerning environmental protection.

Professor Nguyen Tat Dac from IESEM, an expert on flow modelling, addressed the opening speech, followed by Associate Professor Le Van Tan, Vice Chancellor of 
University of Industry. The coordinator of the workshop was Dr. Le Hung Anh from University of Industry of HoChi-Minh City.

\section{Workshop sessions}

\subsection{Air pollution control and management}

The first session of the workshop was "Air pollution control and management" consisting of three oral presentations and three posters. Concerning the oral lectures, the first presenter (Department of Mechanical Engineering, Konkuk University in Republic of Korea) introduced the developed framework design of Integrated Air Quality Management System as an Artificial Intelligent (AI) System, which was utilized to improve the air quality in subway stations. The second speaker (Department of Environmental Engineering, Konkuk University, Republic of Korea) presented the degradation characteristics of aromatic VOCs by using electron beam. The last presenter in the session (Institute for Environmental Science, Engineering and Management, Ho Chi Minh City University of Industry, Vietnam) introduced the modelling of air pollution from road traffic in Ho Chi Minh City. All authors of poster papers came from the Department of Environmental Engineering at Konkuk University, Republic of Korea. The first poster introduced an intelligent monitoring system applied to underground subway stations and tunnels to improve the indoor air quality in Seoul subway. The second and third poster detailed the operating conditions of hybrid adsorption system in a subway station and
$\mathrm{NO}_{2}$ removal efficiency, respectively. Proposals and suggestions with good insight were offered as well.

Starting the "Air pollution control" session, Professor Lee, Jai-Hyo of the Konkuk University, Republic of Korea presented "A Study on Artificial Intelligent System considering the Predictive Model of Subway Station Air Quality". One of Seoul subway stations (D Station) was chosen as an experimental station in this work. The air quality in a subway station can be automatically monitored and controlled through this system. The measurements were conducted in four different compartments in a station so that the particle pollution sources and processes may be identified. From these operations of Information Technology and Energy Technology (IT-ET) and Artificial Intelligent (AI) system, the cleaner-but-greener air quality management system ran smoothly as expected. On the basis of the environmental regulation, Artificial Intelligent (AI) system on waiting room and platform ventilators were operated by only PM10 feedback controller data to control the ventilators. Then a predictive model on the AI system was created to improve the ventilator efficiency and reduce the power consumption. The predictive model is composed of the real time data algorithm, predictive data algorithm and factors etc. At last, the AI system was tested and verified, and it functioned well. When the air quality was only controlled by the feedback controller, the accuracy during the rush hour time was rather insufficient. When the air quality was only controlled by feed forward controller, the air quality level would be high because it was controlled each 30 minutes.

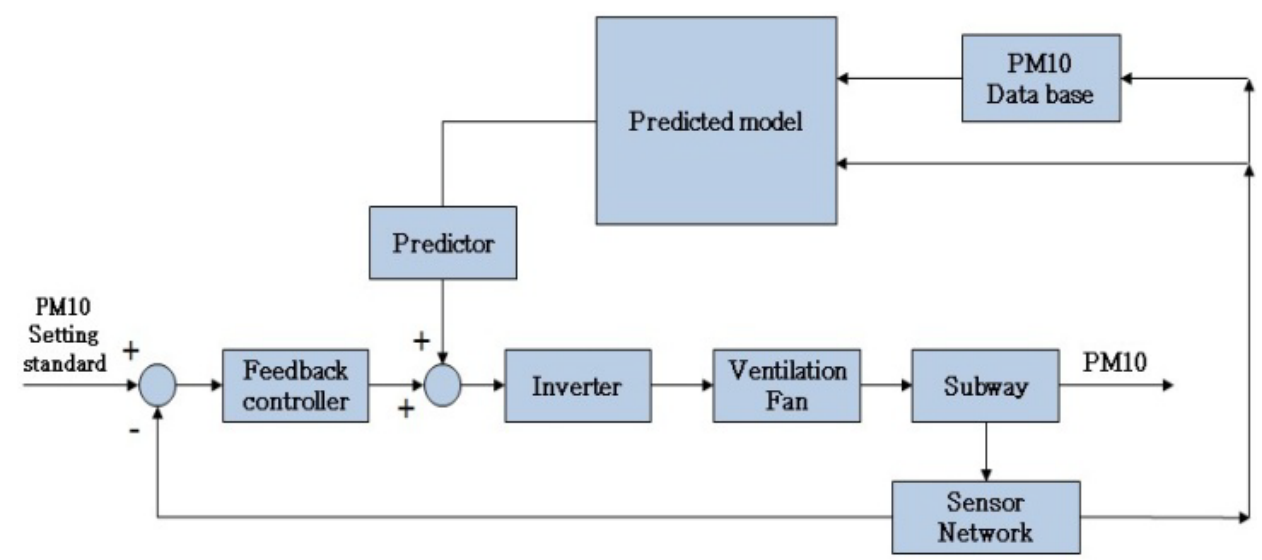

Figure 1. AI system controller block diagram

The AI system consisted of feedback and feed forward controllers, so the best air quality level and the lowest frequency level would be controlled by the AI system while the power consumption would be reduced by $20 \%$ on the rush hour time. The AI system can be applied to every station.

Professor Kim, Jo-Chun from the Konkuk University, Republic of Korea introduced in the second presentation the topic "Control of odorous compounds using electron beam". The degradation characteristics of aromatic volatile organic compounds (VOCs) were investigated by electron beam irradiation using different concentrations, background gases (oxygen, nitrogen, air, and helium), absorbed doses $(\mathrm{kGy}, \mathrm{kJ} / \mathrm{kg})$, relative humidity $(\mathrm{RH})$, and flow pattern. The electron beam accelerator used in this study is $1 \mathrm{Mev}$ ELV4 type with a maximum power of 40 $\mathrm{KW}$. The VOC concentration generated was adjusted based on flux, temperature, and solution amount in a pretest in the laboratory. A GC/FID (HP5890) was used to make quantitative analyses of the samples. HP-1 columns ( $25 \mathrm{~m}, 0.32 \mathrm{~mm}, 520 \mathrm{~mm}$ ) were used for GC/FID analysis. An FTIR type $\mathrm{CO}_{2}$ analyser (Gas data PAQ, Gas data Ltd., UK) was adopted to measure the amount of $\mathrm{CO}_{2}$. The experimental results illustrate that the removal efficiencies of aromatic VOCs generally increase as their concentrations decrease and the doses increase. Addition of water vapour into the reactor of a flow system results in significant increase in VOC removal efficiencies, pre- 
sumably due do $\mathrm{OH}$ radical formation leading to additional degradation pathways.

The last presenter in the session was Dr. Luong, Van Viet from Ho Chi Minh City University of Industry, Vietnam who presented the subject "Modelling of air pollution from road traffic in Ho Chi Minh City". Ho Chi Minh City (HCMC), the largest city in Vietnam, is one of the political, economic, and scientific centres of Vietnam. The traffic system in HCMC consists of 943 roads of $1,275 \mathrm{~km}$ length. The total daily number of engine vehicles is 3,200,000 motorbikes and 500,000 cars. Many vehicles were used for more than 15 years with some of them being constructed in 1970s. The traffic density at the main crossroads in the city is very high therefore the traffic-jams are very frequent.

Table 1. Air pollution measurement sites in HCMC

$\begin{array}{ccll}\text { ID } & \text { Code } & \text { Name } & \text { Characteristic } \\ \mathbf{1} & \text { DO } & \text { DOSTE } & \text { Traffic } \\ \mathbf{2} & \text { HB } & \text { Hong Bang } & \text { Traffic } \\ \mathbf{3} & \text { TD } & \text { Thu Duc } & \text { Res./Ind. } \\ \mathbf{4} & \text { TS } & \text { Tan Son Hoa } & \text { Urb. Bkg. } \\ \mathbf{5} & \text { TN } & \text { Thong Nhat } & \text { Traffic } \\ \mathbf{6} & \text { BC } & \text { Binh Chanh } & \text { Traffic } \\ \mathbf{7} & \text { ZO } & \text { Zoo } & \text { Urb. Bkg. } \\ \mathbf{8} & \text { D2 } & \text { District 2 } & \text { Res./Ind. } \\ \mathbf{9} & \text { QT } & \text { Quang Trung } & \text { Urb. Bkg. }\end{array}$

The traffic activities are more and more developing leading to a considerable increase of air pollution effect on the people's life quality. The meteorological model (MM5 model, FVM model) and the photochemical model (TAPOM model) were applied to study the spatial distribution of traffic air pollution and evaluation of transport vehicle emission dispersion in urban areas. MM5 output is highly accurate due to the combination with the microphysical cloud scheme and cumulus scheme. FVM is simulating in detail the atmospheric phenomena occurring in the boundary layer, which are represented through the components of the equation system. As a result, the meteorological simulation by combining MM5 and FVM has a good initial condition for air pollution model. The gas concentration simulated by the model is close to the in situ data, so that the main reason of HCMC air pollution is associated with vehicle activities. To decrease the ozone pollution in HCMC one has to reduce the number of motorbikes.

In the poster sub-session, Dr. Son, Youn-Suk (Konkuk University, Republic of Korea,) introduced "A rule-based ventilation system to improve indoor air quality in underground subway systems". In this study, an intelligent monitoring system was applied to underground subway stations and tunnels to improve the indoor air quality. Measurements of PM10 and PM2.5 concentrations were carried out at nine monitoring sites in $\mathrm{D}$ and $\mathrm{H}$ stations of the Seoul subway. The nine monitoring locations include three tunnels, two platforms, and two waiting rooms. Two sites outside the subway system were also monitored for comparison. Measuring devices were connected to cable networks to facilitate central data collection and to monitor PM10 and PM2.5 levels from the nine sites at the same time. In this work, ventilation fans were controlled by different monitoring concentrations between indoor and outdoor air quality. As a result, energy costs for ventilation in this subway stations and tunnels were decreased by $21 \%$ and $50 \%$ compared to ordinary operation conditions. Also from Konkuk University, Eng. Hong, JunSeok and Eng. Dinh, Trieu-Vuong introduced the application of activated carbon bed to remove $\mathrm{NO}_{2}$ in Seoul subway station. In general, $\mathrm{NO}_{2}$ caused by automobiles flows into the subway through ventilating openings and stairs, and has harmful effect on passengers. To solve this problem, the control work of $\mathrm{NO}_{2}$ using mixed activated carbon filter has been carried out. Furthermore, $\mathrm{NO}_{2}$ concentrations were measured before and after the filter system. The control efficiency of $\mathrm{NO}_{2}$ in a HVAC system was initially $75 \%$. Based on power consumption inventory, the cost of power consumption per $1 \mathrm{KWh}$ was calculated for the hydride filter system. The estimation indicates that power consumptions were reduced by approximately $40 \%$. When changing the angle of the hybrid carbon bed by $90^{\circ}$, the $\mathrm{NO}_{2}$ concentration in the subway was over $50 \mathrm{ppb}$. When moving down the hybrid carbon bed by $45^{\circ}$, the $\mathrm{NO}_{2}$ concentration in the subway was below $50 \mathrm{ppb}$. Therefore, we lowered the inverter frequency to get the same superficial gas velocity as in normal operating conditions.

\subsection{Water treatment and water management}

The second session was on "Wastewater treatment and water quality management" with a total of three papers presented. The first came from the Department of Environmental Engineering, Dayeh University in Taiwan, introducing the application of electrocoagulation in fabric dyeing, tannery, electroplating industries etc. The presentation encompassed laboratory experiments to commercial units capable of treating up to 1,000 cubic meter of effluent. The second and third papers were from the Ho Chi Minh City University of Industry and Southern Institute of Water Resources Research, which detailed the current status and prospects of water resource in Ho Chi Minh City and Can Tho City, respectively. Proposals and suggestions with good insight were offered as well.

In the presentation "Application of a Pilot-Scale Pulsed Electrocoagulation System to Mill Effluents" of the first presenter, Professor Perng Yuan-Shing of the Dayeh University, Taiwan, introduced the performance of a pilot-scale pulsed electro-coagulation system (Figure 2). 


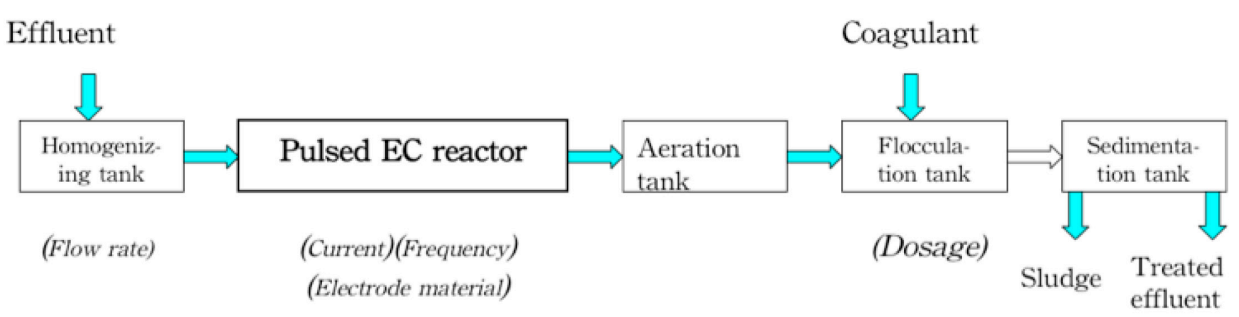

Figure 2. Experimental flow chart with pulsed EC reactor

Wastewater passing through an electrolysis reactor will cause the pollutant to be polarized and precipitated out which increased the removal of $\mathrm{COD}, \mathrm{BOD}, \mathrm{SS}$, true colour, and electrical conductivity. When cast iron or aluminium were used in anode, passing of current produced ions of $\mathrm{Fe}^{2+} / \mathrm{Fe}^{3+}$ or $\mathrm{Al}^{3+}$, which acted as flocculants. Compared to alum or PAC, these ionic species were more effective. Because the electrochemical reactions and less or no requirement of flocculant, the sludge volume was only ca. $50 \%$ of the traditional chemical coagulation. The pulsed electro-coagulation system had been assessed both in the laboratory and at mill sites and is successfully commercialized. All operations of the units are PLC controlled and fully automatic, thus requiring no attendant in routine operations. It is a fairly mature commercial products successfully promoted and applied in Taiwan and China to fabric dyeing, tannery, electroplating, IC waffle, and food industry. For traditional effluent treatments, the recalcitrant electrical conductivity, true colour, and heavy metals problems can be resolved with the system. The operational cost is dependent on the power rate, and mostly within US\$ $0.5 / \mathrm{m}^{3}$. If the afore-mentioned industries in
Vietnam have pollution problems and if traditional treatment methods are unable to economically attain environmental regulation standards, or if the water is intended to be recycled, then perhaps the pulsed electrocoagulation system can be a solution.

The second presenter was Professor Nguyen Tat Dac from the Ho Chi Minh City University of Industry speaking about "Flooding and inundation in Ho Chi Minh city and planning for solutions". The serious flooding and inundation problems faced by HCMC were first reviewed, and then the causes for these events were analysed. In order to effectively resolving these flooding and inundation problems, a concept of hydraulic structures was proffered. The proposed scenarios were A) solution of flooding and inundation at the outer ring; and B1) dikes and 12 tidal gates at the inner ring; B2) solution of discharge and tide control at the interflow of Saigon-Dong Nai Rivers (middle ring); and C) hydraulic structure of flooding and inundation management at the furthest outer ring, installing a tidal barrier of $33 \mathrm{~km}$ connected Vung Tau and Go Cong.

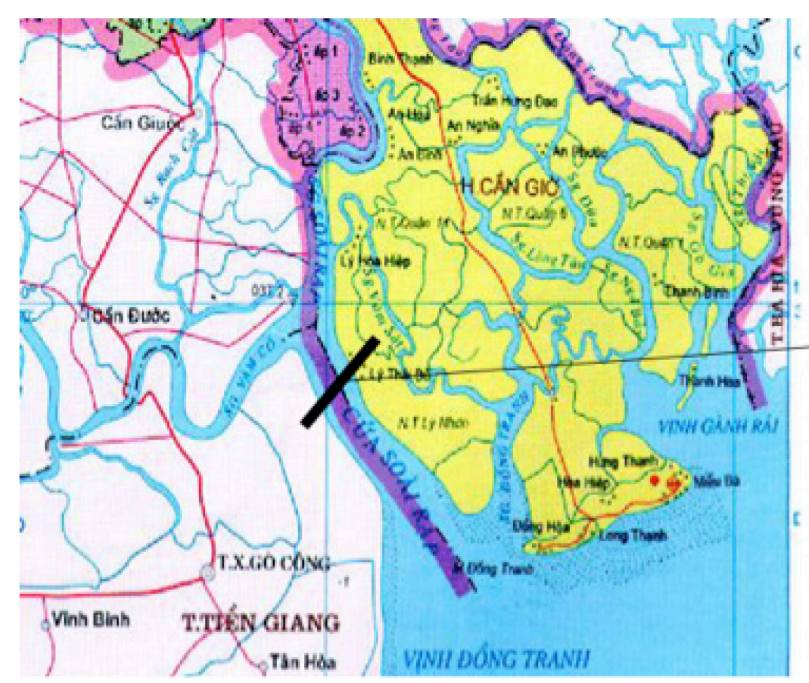

Figure 3. Dam and controlled sluice gate Soai Rap

Based on the different scenarios, data of the flooding situation of 2000 and dry season of 2008 represented the model input and computer simulation analyses and evaluations on the pluses and minuses of the cost, water level, transportation and ecological effects were detailed. The final conclusions were: 1) flooding and inundation in HCMC due to rainfall and high tide is a great concern of people and authority; 2) some planning structural solutions have been proposed; 3) studies and considerations are on-going; and 4) need more and careful studies in topography, geology, geometry and environment for each proposed solution.

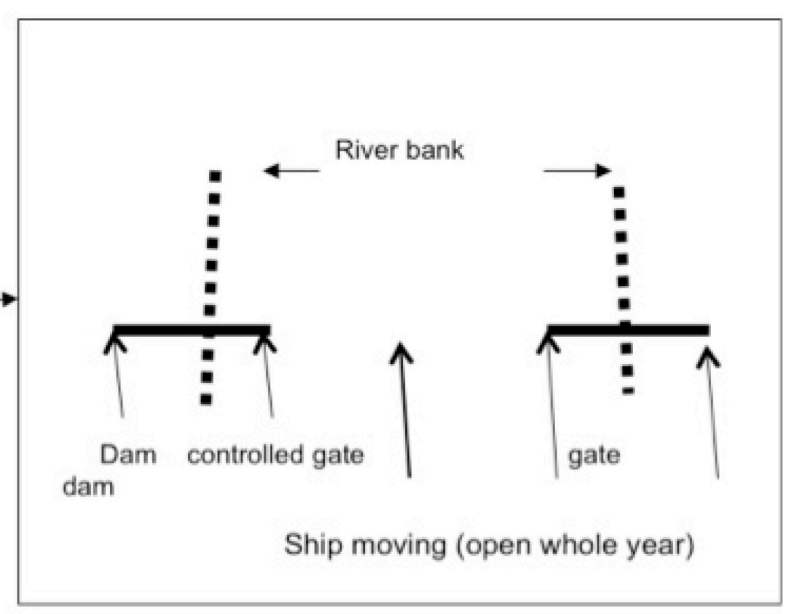

The third presenter was Dr. Trinh Thi Long of the Southern Institute of Water Resources Research with the subject "Solutions for sustainable urban and rural water resources management in dry season toward adaptation to climate change in Can Tho City". The effects of greenhouse gases induced climate change in Vietnam and Mekong Delta regions were first described. The predicted temperature would increase from $33-35^{\circ} \mathrm{C}$ to $35-37^{\circ} \mathrm{C}$; and annual precipitations in An Giang, Can Tho, and Soc Trang would expect to decrease by $20 \%$, while the monsoon rainy season will be delayed by two weeks. Soil salinization is expected to accelerate. In Can Tho City, annual precipitation is 200 billion $\mathrm{m}^{3} /$ year, $81 \%$ of the rainfall occurs at rainy season and $19 \%$ at dry season. 
More seriously, only ca. 4\% of the rainfall occurs from March to May. From 1999-2008, 38 long-term water quality-monitoring campaigns were conducted in Can Tho City. The parameters analysed included COD, total nitrogen, organic matter, pathogens etc. The results indicated that COD came mainly from: 1) domestic wastewater, 2) wastewater of fishponds, and 3) aquatic products processing industry. So, only one of those sources can make water quality in river/canal system of Can Tho City exceed the permissible limitation of the current National Standard QCVN 08:2008/BTNMT. This is the reason why the concentration of COD in surface water is increasing every year even with high flow of Hau river and polluted water washes out to the sea everyday. In order to effectively resolve the problems of climate change and the pollutant sources, a wastewater for irrigation scheme was proposed, which achieved the goals of not having water shortage while reducing COD in effluent. The final conclusions were: 1) conserving the water by recycling and groundwater recharge is a low-cost method for sanitary disposal of municipal wastewater; 2) reduction of pollution of rivers and other surface water; 3 ) conservation of nutrients, thereby reduction of the need for artificial fertilizer; 4) increase in crop yields; 5) provide a reliable water supply to farmers; and 6) use freshwater discharge to push back seawater.

\subsection{Solid waste and energy}

The third session of this workshop was on "Solid waste and energy". There were four scientific reports in the final session: Dr. Ho Chi Anh - the Leader of the Department of Environmental Technology, University of Thu Dau Mot Binh Duong (Vietnam), Prof. Dr. I-Chen Wang - the Leader of the Division of Wood Cellulose \& Division of Forest Chemistry, Taiwan Forestry Research Institute (Taiwan), Dr. Bui Trung Thanh, Head of the Department of the Cold Heat, and Dr. Le Hung Anh - the Head of Department of Environmental Technology - Ho Chi Minh City University of Industry (Vietnam).

The first presenter was Dr. Ho Chi Anh who reported on the topic "A survey on Vietnam solid waste management and private sector participation". In 2012, Dr. Ho Chi Anh and a number of co-authors (Dr. Le Hung Anh - team leader, Mr. Ho Quang Tao, Dr. Vu Hoang Hoa, and Mr. Ngo Van Tuan) compiled a report on solid waste management in order of International Finance Cooperation (IFC), which is a member unit of the World Bank. The report consists of four main tasks: Task 1 - Review of published literature and other available market data, Task 2 - Investigate the status of previous integrated solid waste management efforts, Task 3 - Consult with local stakeholders to understand the practical issues and concerns, Task 4 - Develop scoping report for Vietnamese waste management program.

Vietnam has a population of nearly 89 million people (2012), whose emissions amount each year around 15 million tons of waste distributed as follows: $46 \%$ municipal waste, $32 \%$ waste from agricultural production, $17 \%$ industrial waste, $4 \%$ solid waste from craft villages and $1 \%$ of medical solid waste. The Vietnamese government introduced the program management strategic objectives for National Solid Waste Management 2025 with vision to 2050. The government encourages and supports the participation of the private sector in the process of collecting, recycling and processing into compost and energy production. Some suggestions needed to be supported by the government and World Bank in the future are:

- Compost market improvement

- Sustainable solid waste management for craft villages and rural area

- Advisory program for a deposit refund system for PET bottle recycling.

The second presenter was Prof. Dr. I-Chen Wang who reported on disposal of solid wastes from paper industry using a Catalytic Hydro Thermal Conversion-based Technology (CHTC). The CHTC process appears to be a viable method to transform organic solid wastes with fair amount of water into syngas with good fuel value. Solid wastes from several sources were collected for CHTC process: a) sludge from secondary treatment of an old corrugated container, board (OCC) mill and an integrated pulp and paper mill, b) process rejects from an OCC mill pulper + whiteboard mill pulper and stock preparation system, c) fibrous rejects from a specialty paper mill + wood wastes from sawmills.

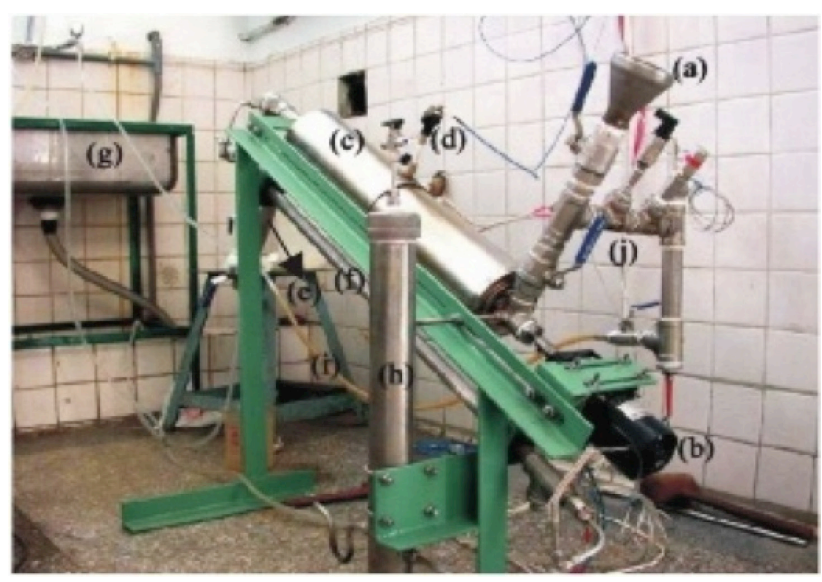

Figure 4. Photo of the CHTC bench-scale reactor setup

The preliminary results indicated that the unit could achieve good conversion of organic-containing solid wastes. The concentration of hydrogen gas in flue gas was fairly high. Based on the observation of Fung and Graham, sodium carbonate in addition to favour steam reformation, produced mainly $\mathrm{CO}$, implying that the flue gases were quite rich in fuel values. A suitable inorganic medium for heat transfer in the reactor is necessary. Sericite powder, a platy mica mineral, appeared to be workable for the purpose.

Overall char and tar productions were minimized with only minor amounts occurring in the after-treatment residues. The original steam injector design was ineffective. Passively generated steam from moist feedstock can supply the necessary steam. Optimization study indicated that the effects of four parameters - particle size (P), catalyst dose $(\mathrm{C})$, medium dose $(\mathrm{M})$, and reaction temperature $(\mathrm{T})$ were dependent on feedstock. For sludge, the most im- 
portant factors were respectively $\mathrm{MT}, \mathrm{PM}, \mathrm{PC}$ interactions, $\mathrm{M}, \mathrm{P}, \mathrm{C}$, and $\mathrm{T}$; for process rejects, the most important factors were respectively $\mathrm{MT}$ interaction, $\mathrm{C}, \mathrm{M}, \mathrm{T}$, $\mathrm{P}$, and PT, PM interactions. The negative MT in both cases suggests that heat transfer remain one of the most critical problems in CHTC. The auger-type reactor has limited treatment capacity and heat transfer will become insurmountable for large reactor of the similar design. Other types of reactors need to be developed for practical purposes.

Dr. Le Hung Anh from University of Industry introduced "Composting sludge from rubber production with different structure rich materials" in the third presentation. Rubber plantation area in the country was up to 834,200 ha in $2011,11.4 \%$ higher compared to 2010 . The rubberprocessing companies produced 811,600 tones of latex. Each ton of natural rubber produces $20-40 \mathrm{~m}^{3}$ of wastewater and about 1-2 $\mathrm{m}^{3}$ of sludge. Currently, the volume of sludge has not been utilized. Thus, environmental companies are hired for burial thereof. On the other hand, to ensure the productivity of latex harvested annually, the rubber-processing companies have to invest much money to buy organic fertiliser on the market. Normally, the quantity of organic fertilizer used is 2,500 $\mathrm{kg} / \mathrm{ha} /$ year for seedlings of rubber trees and 1,200 $\mathrm{kg} / \mathrm{ha} /$ year for mature trees. Research results will be applied in the rubber manufacturing facilities so as to solve the environmental problems arising from sludge and to create organic fertilisers (compost) for rubber plantations.

Table 2. Analysis of heavy metals in rubber sludge compared to the standard that allows the use of sludge for compost production in Poland (PL), Germany (DE) and South Korea (KR)

\begin{tabular}{llllll} 
Element & Unit & Rubber sludge & Limit values (PL) & Limit values (DE) & Limit values (KR) \\
\hline $\mathbf{P b}$ & $\mathrm{mg} / \mathrm{kg}$ & 3.35 & 500 & 200 & 150 \\
$\mathbf{C d}$ & $\mathrm{mg} / \mathrm{kg}$ & 0.13 & 10 & 3 & 5 \\
$\mathbf{C r}$ & $\mathrm{mg} / \mathrm{kg}$ & 27.67 & 500 & 300 & 300 \\
$\mathbf{N i}$ & $\mathrm{mg} / \mathrm{kg}$ & 35.02 & 100 & 100 & 50 \\
$\mathbf{H g}$ & $\mathrm{mg} / \mathrm{kg}$ & 0.035 & 5 & 5 & 2 \\
$\mathbf{A s}$ & $\mathrm{mg} / \mathrm{kg}$ & 0.38 & - & - & 5
\end{tabular}

According to Table 2, the sludge generated during wastewater treatment from natural rubber processing plant is perfectly suited as a material for organic fertiliser production (compost). To optimize the composting process, additives must be added to the sludge of carbon-rich organic and structured material. Coir is a material that has been proved to be very suitable, with a mixing ratio of 10 $15 \%$. The additives that also give good results are water hyacinth $(4 \%)$, or rice husk $(5 \%)$. The addition of useful microorganisms in the process of composting has confirmed the advantages: with less arising bad odour, producing compost as finished products with higher useful micro-organisms density and reduction of coliform density. Compared to the standard German compost, the compost products from rubber sludge have significantly higher content of organic matter, N, P, K, while the compost moisture is high (over 50\%). Thus, additional steps are required to reduce humidity if manufacturing facilities wish to register as fertiliser traders.

The last presenter was Dr. Bui Trung Thanh of University of Industry with the subject "Engineering design and fabrication of waste cassava pulp presser". The waste cassava pulp is one of main causes of environment pollution problem of starch processing plants (it gets yellow colour and has "dead rat smell"). Various analyses indicated that the dry matter of waste cassava pulp consists of $70-74 \%$ cellulose, $20-30 \%$ protein and 3-5\% starch. This dry matter is useful for animal feeding. The technical solutions to solve pollution are mainly based on reusing approach. Waste cassava pulps are extracted first to squeeze out water by belt presser. The presser consists of two belts, two main drums with suitable holes density ratio and holes drilled on the surface, auxiliary rollers and a knife assembly which is used to cut the finished product at the out door of the presser. The machine can extract free water in the pulp with final moisture content of 60-62 $\%$ (the moisture content of raw pulp is over $80 \%$ ). The final result of the two belts presser is better than the one belt and one drum presser or the one belt two drums presser reported by several researchers over the past years. 


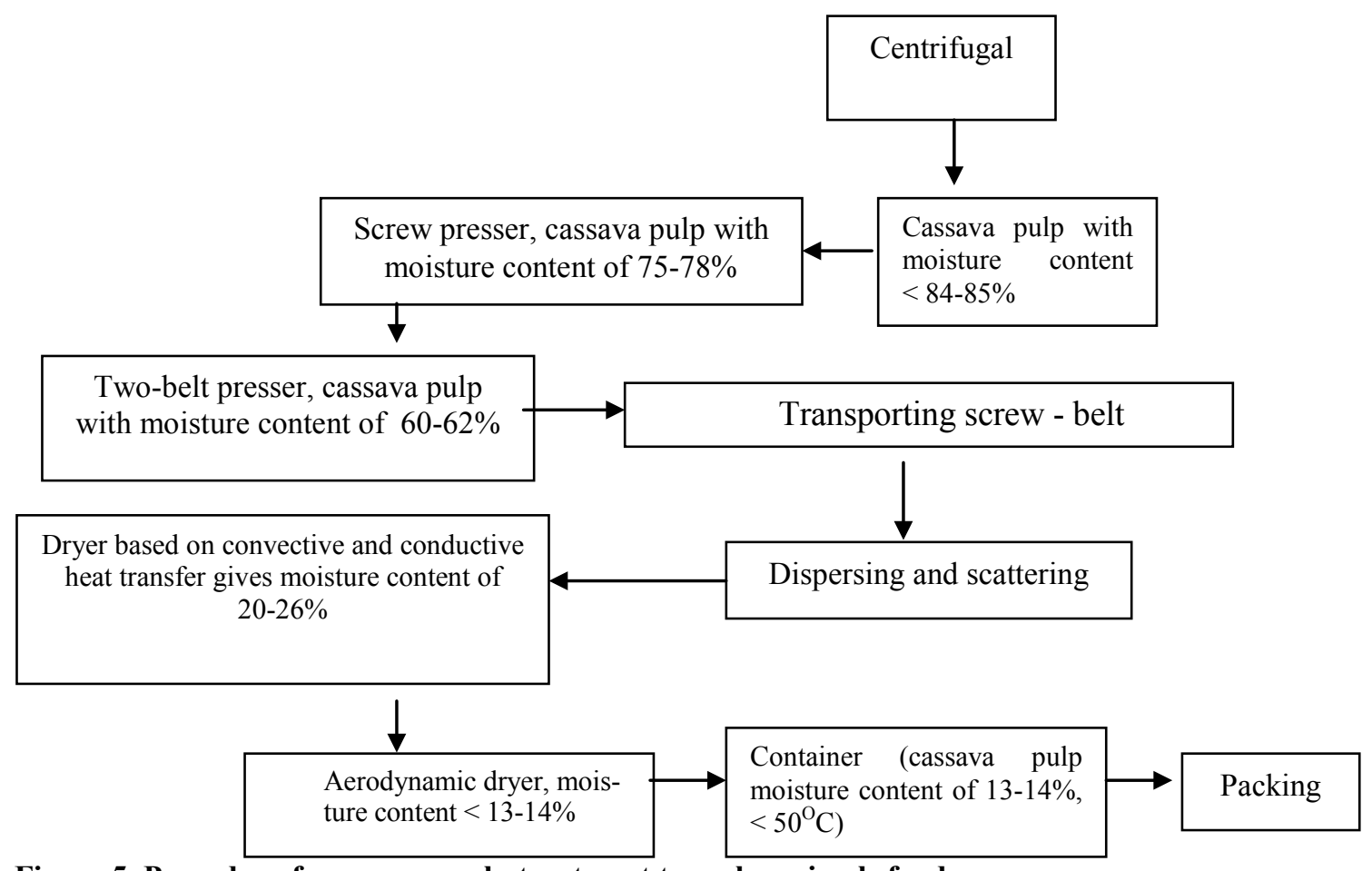

Figure 5. Procedure for cassava pulp treatment to make animals foods

The final product quality of the two belts presser depends on density and size of the hole of the belt when the surface of the main pressed drums is over $40 \%$. The thickness layer of the raw pulp which stands between two belts is $4.5-5 \mathrm{~mm}$ only. The operator should set the right position of the knife to cut good finished outputs. The speed of the belt should be adjusted from 0.5 to $0.65 \mathrm{~m} / \mathrm{s}$.

Two-belt presser, well inherited from the prominent world class pressers, proves to be very encouraging with low specific power, high efficiency, low remaining cassava pulp moisture content and high uniformity comparing to other structures in dealing with challenging problems encountered in factories specializing in starch production. An additional investment of the factories can yield high efficacy in terms of both economy by making co-products and pollution resolution. The success of this kind of presser is not only limited within starch production factories but also in perspective of mud treatment for industry.

\section{Conclusion of the workshop}

At the end of the workshop, Prof. Nguyen Tat Dac and Professor Kim, Jo-Chun led the session dedicated to final discussions and conclusions. The exchange of information done in the workshop proved to be very useful for the audience. The advice provided by the advisory board to the scientists attending the workshop was of high relevance for the continuation of the network. The sessions allowed the identification of the most interesting additives to be studied in different countries of ANEE. Complying with one of the main objectives of the workshop, different contacts were made between partners for further collaboration.

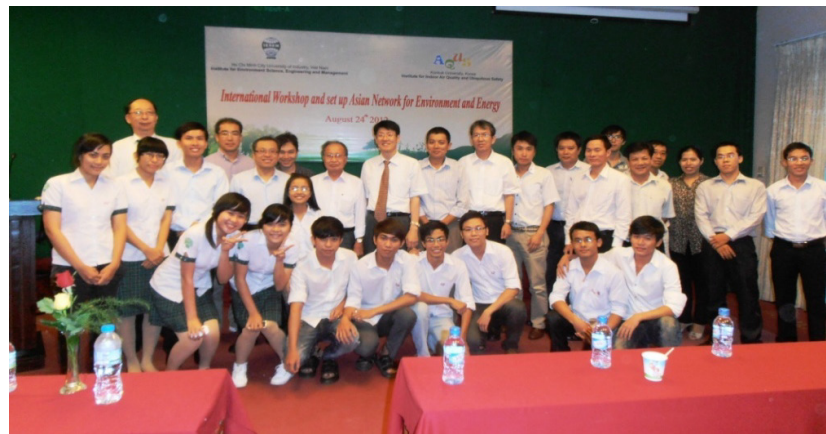

Figure 6. Memorandum photo of the workshop

One of the main workshop outcomes was the agreement between partners about the cooperation in the future. A memorandum of bilateral cooperation was signed as a basis for registration of research topics and international training according to the programs for international cooperation of the Institute for Environmental Science, Engineering and Management from Ho Chi Minh City University of Industry with the Institute for Indoor Air Quality and Ubiquitous Safety from Konkuk University, Department of Chemical Engineering from Konkuk University and Department of Environmental Engineering from DaYeh University.

The host organized for the international guests a visit at rubber processing enterprises, which have environmental problems such as odour, wastewater and sludge treatment, and energy recovery (biogas) from wastewater. Moreover, the international delegates also had the opportunity to learn the Buddhist culture of Vietnam, visiting Ho Chi Minh City and enjoying traditional food of the southern Vietnam. 


\section{Acknowledgements}

The workshop was sponsored by the Ho Chi Minh City University of Industry and co-sponsored by the Department of Environmental Engineering of Konkuk University. The authors would like to acknowledge the staff members of IESEM for perfect workshop implementation, as well as Mr. Dinh Trieu Vuong who came from Ho Chi
Minh City University of Industry and conducted research work in the laboratory of AQUS from Konkuk University, as well as for his efforts to establish contacts and provide support to the workshop. Many thanks go also to the invited speakers for their valuable contributions and last, but not least, to all workshops' participants for their interest in the presented topics. 